\title{
Predictors of persistent cytologic abnormalities after treatment of cervical intraepithelial neoplasia in Soweto, South Africa: a cohort study in a HIV high prevalence population
}

\author{
Yasmin Adam*1,2, Cyril J van Gelderen ${ }^{1,2}$, Guy de Bruyn'3 , James A McIntyre3, \\ Diane A Turton ${ }^{2,4}$ and Neil A Martinson ${ }^{3,5}$
}

Address: ${ }^{1}$ Department of Obstetrics and Gynaecology, Chris Hani Baragwanath Hospital, Johannesburg, South Africa, ${ }^{2}$ University of the Witwatersrand, Johannesburg, South Africa, ${ }^{3}$ Perinatal HIV Research Unit, University of the Witwatersrand, Johannesburg South Africa, ${ }^{4}$ National Health Laboratory Service, Johannesburg, South Africa and ${ }^{5}$ Johns Hopkins University School of Medicine, Baltimore, USA

Email: Yasmin Adam* - yasminadam@gmail.com; Cyril J van Gelderen - cjvangel@gmail.com; Guy de Bruyn - debruyng@hivsa.com; James A McIntyre - mcintyre@hivsa.com; Diane A Turton - dianne.turton@nhls.ac.za; Neil A Martinson - martinson@hivsa.com

* Corresponding author

Published: 25 July 2008

BMC Cancer 2008, 8:21I doi:10.1186/147|-2407-8-21I
Received: 6 January 2008

Accepted: 25 July 2008

This article is available from: http://www.biomedcentral.com/I47I-2407/8/2। I

(C) 2008 Adam et al; licensee BioMed Central Ltd.

This is an Open Access article distributed under the terms of the Creative Commons Attribution License (http://creativecommons.org/licenses/by/2.0), which permits unrestricted use, distribution, and reproduction in any medium, provided the original work is properly cited.

\begin{abstract}
Background: In the presence of both HIV infection and cervical intraepithelial neoplasia (CIN), the risk of cancer development despite treatment may be greater. We investigated clinical predictors of persistent cytological abnormalities in women who had had a large loop excision of the transformation zone (LLETZ).
\end{abstract}

Methods: Women with high grade squamous intraepithelial lesions or worse (HSIL), less severe abnormalities which persisted and any abnormality in women who are HIV-infected, were referred to the colposcopy clinic. HIV infection was ascertained by self-report. A LLETZ was performed on all patients with HSIL or higher on Papanicolaou (Pap) smear or colposcopy, LSIL or higher in patients who are HIV-infected, where the colposcopy is inadequate, and when there was a discrepancy between colposcopy and cytology by one or more grades. Women with abnormal follow-up smears were compared to those with normal smears. We examined the association between abnormal follow-up smears and demographic and clinical predictors using logistic regression

Results: The median time between LLETZ and first follow-up Pap smear was rather short at I22 days. Persistent cytological abnormalities occurred in $49 \%$ of our patients after LLETZ. Predictors of persistence included the presence of disease at both margins and HIV infection. Among the latter, disease at the excision margins and CD4+ cell count were important predictors. In these women, disease at the endocervical margin, both margins, and disease only at the ectocervical margin were associated with increased odds of persistent abnormalities on follow-up cervical smear.

Conclusion: We showed extremely high risk of cytological abnormality at follow-up after treatment more so in patients with incomplete excision and in the presence of immunocompromise. It remains uncertain whether recurrent $\mathrm{CIN}$ is a surrogate marker for invasive cervical cancer. 


\section{Background}

Cervical cancer is the second leading cancer in women after breast malignancy in South Africa (SA)[1]. The lifetime risk of developing invasive cervical cancer (ICC) is 1 in 31 for South African women. The crude rates for ICC were 26.1 per 100000 in 1999 , with a corresponding agestandardized incidence rate of 28.7 per 100000 and the risk increased with age, peaking at 136.4 per 100000 in women between the ages of 65 and 69[2]. Worldwide, the ratio of mortality to incidence is $55 \%$ with a worse prognosis in developing countries[1].

Several studies from Sub-Saharan Africa have shown associations between HIV infection and cervical cancer [3-5]. Furthermore, in HIV-infected women, premalignant disease of the cervix is more frequent, of a higher grade, and progresses more rapidly[6]. The prevalence of abnormal Pap smears was between $50 \%$ and $75 \%$ in HIV-positive women in two studies in Sub-Saharan Africa[7,8] and in the Gauteng province of SA, where our clinic is situated cervical cytological abnormalities are found in $13.7 \%$ of all women. This is a surprisingly high prevalence even allowing for a high HIV infection rate $(30.8 \%$ in antenatal attendees in the same community[9]).

The prevention of ICC includes screening for pre-malignant disease, treatment and follow-up of treated patients. A National Screening Policy, whereby state health will pay for three cervical smears in a life-time commencing at the age of thirty, was instituted in SA in 2001[10]. By the year $2006,5.2 \%$ of screened women were being referred for colposcopy in the Johannesburg Metropolitan area compared to $3.5 \%$ in the UK $[11,12]$.

Local excision and ablation of the cervix is the standard treatment for CIN2-CIN3. Although treatment reduces the risk of subsequent ICC $[13,14]$, these women remain at a 5 -fold increased risk of ICC as compared to the general population[15]. Follow-up for recurrent CIN is therefore an important aspect of the prevention of cancer program. The identification of meaningful risk factors for persistence will not only pinpoint, those who need to be followed up more actively after treatment of a premalignant lesion, but may designate those who may safely be followed at less sophisticated facilities, and perhaps at less frequent intervals. The objective of this study was to document rates and predictors of persistence of premalignant cervical lesions in women who had had a large loop excision of the transformation zone (LLETZ) at a "see and treat" colposcopy clinic in Soweto, South Africa.

\section{Methods}

We followed up a cohort of women attending the colposcopy clinic at Chris Hani Baragwanath Hospital in Soweto, South Africa. The clinic is a referral site for women with abnormal cervical smear results who pre- dominantly live in Soweto but also are referred from the southern parts of the Province. Cytological cervical smears are reported according to the 2001 Bethesda System Terminology[16]. These reports include: invasion, high or low grade squamous intraepithelial lesion (HSIL or LSIL), atypical glandular cells of undetermined significance (AGUS), atypical squamous cells suggesting HG (ASC-H) or atypical cells of undetermined significance (ASCUS).

Initially HIV status was ascertained by self-report. Voluntary counseling and testing (VCT) was only started in November 2006. HIV positive results were confirmed by clinical notes of women who self-reported being HIV positive. The status of those patients who said that they were HIV negative was recorded as such if the test was done within the last 6 months. However the result was not always confirmed. Those who said they tested negative more than 6 months previously was recorded as unknown.

We offer a "see and treat service" where such patients are offered immediate diagnosis and treatment with colposcopy and LLETZ [17]. A LLETZ is performed on all patients with HSIL or higher on cervical smear or CIN 2 or higher on colposcopy, where the colposcopy is inadequate, or when there is a discrepancy between colposcopy and cytology by one or more grade. HIV-infected women with L SIL or more on cervical smear and CIN 1 or higher on colposcopy are treated due to the higher progression[6] and recurrence in these women.

Patients were followed up at six-monthly intervals. Those women who had not returned by 6 months were contacted by mail or telephone; if there was no response, a letter was hand delivered by a research worker to the listed home address to encourage follow up or to ascertain survival. The total number of patients that were lost to follow-up was $420(41.3 \%)$. The loss to follow-up according to HIV status was $176(42 \%)$ for HIV positive women, $109(26 \%)$ for HIV negative women (self-reported) and $135(32 \%)$ for the women who did not know their status.

Owing to the study design, we cannot differentiate between persistence and recurrence of abnormal lesions. For the purpose of this study, therefore, any abnormal cytology after LLETZ was defined as being persistent. Ethical approval for this study was obtained from the Human Research Ethics Committee (medical) of the University of the Witwatersrand.

\section{Statistical analyses}

Women with abnormal follow-up smears were compared to those with normal smears using t-tests for continuous variables and Chi-square tests for categorical variables. We examined the association between abnormal follow-up smears and demographic and clinical predictors using 
logistic regression. Bivariate association between the outcome of interest and predictor variables was first performed. Multivariate association was then examined in a stepwise logistic regression including only those variables with a bivariate $p$-value of 0.2 or greater. Two separate models were investigated. The first included all participants, and included HIV status as a predictor variable. The second model restricted the analysis population to women who were HIV-infected.

\section{Results}

Between April 2003 and November 2006, 1186 women were referred to the colposcopy clinic at Chris Hani Baragwanath Hospital (CHB) in Soweto. Of these, 1016 had a LLETZ performed and 575 (57\%) women returned to the clinic for a follow-up cervical smear and were included in this analysis (Figure 1). LLETZ treatment was not offered to 170 women: 116 of whom were not eligible for treatment at the time (pregnancy, normal cervix on colposcopy, CIN 1 in immunocompetent women), 38 had invasive cervical cancer, and 15 required hysterectomy for other reasons. 290 women had normal follow-up cervical

\section{Patients referred for colposcopy}

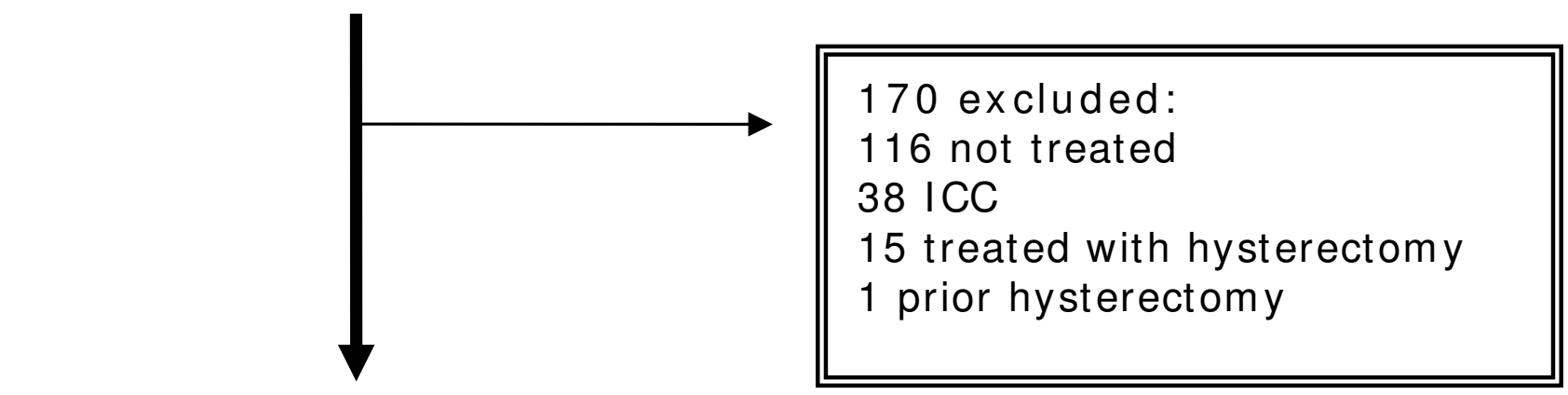

\section{Patients treated with LLETZ}

\section{Patients with follow up cervical smear}

Figure I

Study schema. 
smears(50.4\%) and 285(49.4\%) women had persistently abnormal smears after LLETZ. We included any abnormal Pap smear after treatment in the group classified as persistence, that is any grade of abnormality and any Pap smear after treatment.

The median time from the date of LLETZ to second cervical smear was 122 days (interquartile range (IQR), 71 160 days). There was no difference in the average duration between LLETZ and follow-up smear for those with an abnormal(136.1 days) and those with a normal follow-up smear(136.3 days). There were 80 women who had a second procedure in the group with persistence (LLETZ, cone or hysterectomy). Second treatments were postponed in some women to allow initiation of ARV therapy or in women who were not medically fit for surgery. We did not perform colposcopic examinations on the women with normal follow-up cytology. The cytologic abnormalities noted on the follow up smears are listed in Table 1.

Four women had Microinvasion on histology after LLETZ, one fell pregnant, 2 refused hysterectomy, and one had a hysterectomy 6 months after the LLETZ. There was no dysplasia, only features of HPV infection on the histology. All 4 cases were a stage $1 \mathrm{a} 1$.

Age, HIV infection, histology of the excised portion and the presence of disease at an excision margin were notable differences between those women with persistent cytologic abnormalities and those with normal follow up smears (Table 2). We examined associations of women having an abnormal cervical smear at their follow-up visit with various clinical predictors using logistic regression (Table 3). Self-reported HIV status and the presence of disease at both margins were strongly associated with persistent cytologic abnormalities after LLETZ. Restricting the analysis only to those women who self -reported themselves to be HIV-infected, increasing CD4 count (the CD4 count was the count within 6 months of the treatment date) was found to be associated with lower odds of abnormal follow-up smear results, but having either the endocervical or both margins involved was highly associated with persistent cytologic abnormalities. In addition,

Table I: Results Of Follow Up Cytologic Smears Following Large Loop Excision Of The Transformation Zone (LLETZ), Chris Hani Baragwanath Hospital, Soweto 2003 - 2006.

\begin{tabular}{lc}
\hline Normal cervical cytology at follow-up & $\mathbf{2 9 0}(\mathbf{5 0 . 4 \% )}$ \\
Cytological abnormalities at follow up & $\mathbf{2 8 5}(\mathbf{4 9 . 6 \% )}$ \\
ASCUS & $18(6.3 \%)$ \\
L SIL & $136(47,6 \%)$ \\
ASC-H & $5(1.8 \%)$ \\
AGUS & $1(0.4 \%)$ \\
H SIL & $123(43.2 \%)$ \\
Invasion & $2(0.7 \%)$
\end{tabular}

the presence of CIN3 on the excised tissue resulted in a marked increase in the risk of recurrence compared to CIN1 $(\mathrm{OR}=3.8, \mathrm{CI}=1.1-13.1)($ Table 4$)$.

\section{Discussion}

We report high rates of persistence of cytological abnormalities on a follow-up cervical smear after initial treatment using LLETZ particularly in women self reporting as being HIV-infected. Cytological abnormalities after LLETZ were eight times more frequent in women who self reported as being HIV infected. However, in HIV-infected women with a CD4 count of $\geq 500$ cells $/ \mathrm{mm}^{3}$, this risk was halved when compared to women with a CD4 count of $<200$ cells $/ \mathrm{mm}^{3}$. Dysplasia at both the endocervical and ectocervical excision margins markedly increased the risk of persistence as compared to absent dysplasia at the margins $(\mathrm{OR}=10.7, \mathrm{CI}=3.0-37.4)$. In univariate analysis, the risk of persistence with disease present at either excised margin was double that of no disease at the margin.

The association of HPV and cervical cancer has been established[18]. Impaired cell mediated immunity is a risk factor for HPV infection and CIN[19]. Observational studies have shown an association between CIN and co-infection with HPV and HIV [20]. In this study it was not possible to distinguish between the effect of HIV infection and changes in immunity as would be expected in women on ARV therapy.

Of the 266 women who were HIV-infected, 89(33\%) of them were on ARV therapy and the number of women taking ARV's were significantly higher in the patients with subsequent persistence. However, duration of and response to treatment would be required to assess ARV therapy as an independent variable predicting persistence and we did not collect this information. Longitudinal studies of detection of oncogenic HPV types and cytologic dysplasia among HIV infected women on HAART indicate that ARV therapy may result in clearance of HPV and regression of low grade lesions [21-23].

The histological report contributed to the identification of women at higher risk of persistence. Firstly, univariate analysis of the entire group suggests that if the excised biopsy specimen had margins involved, risk of persistence was significantly higher. In multivariate analysis, this effect was marked. However, because of the relatively small numbers of women in the multivariate analysis, the ability to draw conclusions from this finding is somewhat limited. Secondly, histological reports of CIN-2 and CIN3 increased the risk of persistence compared to CIN-1. In addition, a surprising finding in this study was that increasing age appeared to be protective against persistence as the reported risk of cervical malignancy increases 
Table 2: Characteristics Of Women With Normal Or Abnormal Follow Up Cytologic Smears Following LLETZ, Chris Hani Baragwanath Hospital, 2003 - 2006.

\begin{tabular}{|c|c|c|c|}
\hline & $\begin{array}{l}\text { Abnormal* } \\
(n=285)\end{array}$ & $\begin{array}{l}\text { Normal* } \\
(n=290)\end{array}$ & p-value \\
\hline Age, mean (sd) & $35.1(8.0)$ & $37.5(8.9)$ & 0.001 \\
\hline Parity, mean (sd) & $2.7(1.02)$ & $2.98(0.97)$ & 0.004 \\
\hline \multicolumn{4}{|l|}{ Contraceptive method, $\mathrm{n}(\%)$ reporting use } \\
\hline Norethisterone oenanthate & $32(11.2)$ & $43(14.8)$ & 0.200 \\
\hline Depomedroxyprogesterone acetate & $29(10.2)$ & $48(16.6)$ & 0.025 \\
\hline Intra-uterine contraceptive device & $3(1.1)$ & $4(1.4)$ & 0.721 \\
\hline Progestogen-only pill & $3(1.1)$ & $7(2.4)$ & 0.212 \\
\hline Combined oral contraceptive & $20(7.0)$ & $26(9.0)$ & 0.389 \\
\hline Sterilization & $9(3.2)$ & $19(6.6)$ & 0.059 \\
\hline HIV status, $n(\%)$ self-reporting status & & & $<0.0001$ \\
\hline Negative & $37(13.0)$ & $112(38.6)$ & \\
\hline Positive & $184(64.6)$ & $82(28.3)$ & \\
\hline Unknown & $64(22.5)$ & $96(33.1)$ & \\
\hline CD4, n (\%) & & & $<0.0001$ \\
\hline$<200$ & $91(55.5)$ & $23(3 I . I)$ & \\
\hline $200-499$ & $59(36.0)$ & $33(44.6)$ & \\
\hline$>499$ & $14(8.5)$ & $18(24.3)$ & \\
\hline On antiretroviral therapy & $68(23.86)$ & $21(7.24)$ & $<0.0001$ \\
\hline Baseline smear result, $\mathrm{n}(\%)$ & & & 0.947 \\
\hline H SIL & $216(75.8)$ & $196(67.6)$ & \\
\hline L SIL & $34(11.9)$ & $33(11.4)$ & \\
\hline ASCUS & $12(4.2)$ & $12(4.1)$ & \\
\hline Histology of excised transformation zone, $n(\%)$ & 270 & 255 & 0.139 \\
\hline Normal & $6(2.2)$ & $7(2.8)$ & \\
\hline CIN I & $18(6.8)$ & $28(11.3)$ & \\
\hline CIN II & $116(43.9)$ & $90(36.3)$ & \\
\hline CIN III & $129(48.9)$ & $126(50.8)$ & \\
\hline Microinvasion & $\mathrm{I}(0.4)$ & $4(1.6)$ & \\
\hline Presence of dysplasia at the margin of excised transformation zone & 253 & 243 & $<0.0001$ \\
\hline Both & $35(13.8)$ & $14(5.8)$ & \\
\hline Ectocervical & $84(33.2)$ & $46(18.9)$ & \\
\hline Endocervical & $35(13.8)$ & $35(14.4)$ & \\
\hline Margins clear & $99(39.1)$ & $148(60.9)$ & \\
\hline
\end{tabular}

* Numbers in each category may not sum to the total for the column owing to missing values.

with age, peaking at 136.4 per 100000 in women between the ages of 65 and 69 in South Africa[2].

In this study, we did not see an association between persistent cytologic abnormalities and use of hormonal contraception. This was not thoroughly investigated. Resumption of safe sex practices is associated with regression in women with established neoplasia[24,25]. Condom usage has previously been shown to be higher in women who are HIV positive[26]. This could not be explored in this study, again limited by the ascertainment of condom use.

Potential sources of bias in this study include its operational nature. In this setting, not all eligible women were responsive to visit reminders or other measures to encourage follow up.
In most of the women in this report, we relied on selfreport for HIV serostatus. Even though HIV positivity could be confirmed by clinical notes, women who reported an HIV negative status could not always be confirmed. In South Africa the stigma of being HIV infected causes many people to deny their HIV infection. It is probable, therefore that misclassification would err in the direction of women reporting themselves as HIV-negative, and, if this is so, the associations we have drawn may be an underestimate. Compliance rates for treatment of SIL range widely, $30 \%-73 \%[27,28]$, depending on the setting (e.g., in a developing vs. an inner city population). Furthermore, we did not record the size of the lesion on colposcopy nor size of the excised lesion. We did not record the smoking history or a detailed sexual history and therefore were unable to adjust for them in the regression models. The numbers of abnormal cervical smears may have been inflated by including those that do not tra- 
Table 3: Logistic regression using data of all women whose HIV status was known showing associations with persistence of an abnormal smears following LLETZ $(n=295)$.

\begin{tabular}{|c|c|c|c|}
\hline & $\begin{array}{l}\text { Univariate } \\
\text { Odds Ratio } \\
(95 \% \mathrm{Cl})\end{array}$ & $\begin{array}{l}\text { Multivariate } \\
\text { Odds Ratio } \\
(95 \% \mathrm{Cl})\end{array}$ & $p$-value \\
\hline HIV infection & $6.8(4.3-10.7)$ & $8.2(4.2-15.8)$ & $<0.0001$ \\
\hline \multicolumn{4}{|c|}{ Disease at excision margin of biopsy specimen } \\
\hline No disease at the excision margins & Referent & Referent & - \\
\hline Disease at the Ectocervical margin & $2.1(1.4-3.2)$ & $2.2(1.2-4.1)$ & 0.013 \\
\hline Disease at the Endocervical margin & $0.96(0.6-1.6)$ & $2.1(0.9-5.5)$ & 0.09 \\
\hline Both endocervical and ectocervical margins & $2.6(1.4-5.0)$ & $10.7(3.0-37.4)$ & $<0.0001$ \\
\hline \multicolumn{4}{|l|}{ Histology } \\
\hline CINI & Referent & Referent & - \\
\hline CIN2 & $2.0(1.0-3.9)$ & $2.0(0.8-5.1)$ & 0.17 \\
\hline CIN3 & $1.6(0.8-3.0)$ & $2.2(0.8-6.0)$ & 0.12 \\
\hline Micro-invasion & $0.4(0.04-3.8)$ & $2.00(0.04-96.7)$ & 0.73 \\
\hline Age $>35$ years (median age) & $0.64(0.5-0.9)$ & $0.58(0.33-1.0)$ & 0.06 \\
\hline
\end{tabular}

$(n=295)$.

ditionally require immediate treatment. However, an audit at our clinic in 2006 showed that patients with cervical smears demonstrating L SIL had CIN2/3 on histological examination of excised biopsy specimens in $68.5 \%[29]$. HPV testing is not routinely available in our clinical setting.

Factors previously shown to predict persistence of premalignant cervical lesions include the presence of disease at the margins[30], the grade of CIN [30], oncogenic HPV types[31], HPV variants[30], immunocompetence unrelated to HIV factors, age, smoking[32], and sexual behaviour[33]. In some studies, clear margins did not guarantee eradication [34-36]. Lesion size has a variable association with persistence[37] and the presence of disease at the excision margins may be related to lesion size or excision technique but we did not see any difference in rates of persistence between the two operators (data not shown). In addition, the choice of treatment modality impacts on rates of persistence. Among HIV-infected women, persistence of SIL after Cryotherapy has been reported to be between $48 \%$ and $100 \%$, and after conization between $18 \%$ and $71 \%[38,39]$.

More intensive, long-term follow-up of HIV infected women after LLETZ is warranted and provider-initiated HIV testing should therefore be offered in any patient with an abnormal cervical smear result, to enable appropriate

Table 4: Logistic regression assessing associations with persistence of abnormal smears following LLETZ: restricted to HIV-infected women $(n=196)$.

\begin{tabular}{|c|c|c|c|}
\hline & $\begin{array}{l}\text { Univariate } \\
\text { Odds Ratio } \\
(95 \% \mathrm{Cl})\end{array}$ & $\begin{array}{l}\text { Multivariate } \\
\text { Odds Ratio } \\
(95 \% \mathrm{Cl})\end{array}$ & $p$-value \\
\hline \multicolumn{4}{|l|}{ CD4 category (cells/mm³) } \\
\hline$<200$ & Referent & Referent & - \\
\hline $200-499$ & $0.45(0.24-0.85)$ & $0.4(0.2-0.8)$ & 0.017 \\
\hline$\geq 500$ & $0.2(0.085-0.45)$ & $0.1(0.01-0.2)$ & 0.000 \\
\hline \multicolumn{4}{|l|}{ Disease at excision margins } \\
\hline Margins not involved & Referent & Referent & - \\
\hline Ectocervical margin positive & $1.7(0.93-3.3)$ & $2.0(0.9-4.6)$ & 0.089 \\
\hline Endocervical margin positive & $2.2(0.8-5.8)$ & $5.6(1.3-24.8)$ & 0.024 \\
\hline Both endo- and ectocervical margins involved & $2.5(0.86-7.1)$ & $4.3(0.9-19.2)$ & 0.059 \\
\hline \multicolumn{4}{|l|}{ Histology of excised transformation zone } \\
\hline $\mathrm{CINI}$ & Referent & Referent & - \\
\hline CIN2 & $2.1(0.8-5.3)$ & $2.5(0.8-7.8)$ & 0.116 \\
\hline CIN3 & $2.5(0.96-6.4)$ & $3.8(1.1-13.1)$ & 0.037 \\
\hline
\end{tabular}


follow up arrangements. Furthermore, our data suggests that complete excision of the transformation zone should be the objective of surgical interventions, despite the potential for an increase in associated procedural complications. In our setting, it appears reasonable for HIV negative women who have clear excision margins to have less intensive follow up, at the level of a community health centre.

\section{Conclusion}

We have observed extremely high rates of persistence of CIN in HIV-infected women and in women with disease at the excision margins following LLETZ. More intensive follow up of women with margins involved by CIN and especially women who are HIV infected with CD4 count under 500 is warranted. However, it remains unclear whether persistent CIN identifies those women at risk for progression to ICC.

\section{Competing interests}

The authors declare that they have no competing interests.

\section{Authors' contributions}

YA conceived of the study, performed the surgical treatments, and participated in the design of the study and drafting of the manuscript. CJvG performed the surgical treatments and contributed to the drafting of the manuscript. GdB participated in the drafting of the manuscript and performed the statistical analysis. DAT performed and supervised the histological analysis of all the specimens. JAMcI contributed to the drafting of the manuscript. NAM contributed to the design and drafting of the manuscript. All authors read and approved the final manuscript.

\section{Acknowledgements}

Frans van der Linde from the PHRU assisted with data management and Kevin Newell designed the initial database and performed preliminary analyses. The Gauteng Department of Health funded patient care. Partial support for this study was provided by the US National Institute of Allergy and Infectious Diseases (NIAID) through the Comprehensive International Program of Research on AIDS (CIPRA) network, Grant U19 AI532 77 (CIPRA$\mathrm{SA})$. The content of this publication does not necessarily reflect the views or policies of NIAID, nor does mention of trade names, commercial projects, or organizations imply endorsement by the US Government.

\section{References}

I. Parkin DM, Bray F, Ferlay J, Pisani P: Global Cancer Statistics, 2002. CA: a cancer journal for clinicians 2005, 55(2):74- 108.

2. Mqoqi N, Kellett P, Sitas F, Jula M: Incidence of histologically diagnosed cancer in South Africa, 1998-1999. In National cancer registry Johannesburg ; 2004.

3. Newton R, Ziegler J, Beral V, Mbidde E, Carpenter L, Wabinga H, Mbulaiteye S, Appleby P, Reeves G, Jaffe H: A case-control study of human immunodeficiency virus infection and cancer in adults and children residing in Kampala, Uganda. Int J Cancer 200I, 92(5):622-627.

4. Gichangi PB, Bwayo J, Estambale B, De Vuyst H, Ojwang S, Rogo K, Abwao $H$, Temmerman $M$ : Impact of HIV infection on invasive cervical cancer in Kenyan women. AIDS 2003, I 7(13): 1963-1968.
5. Sitas F, Pacella-Norman R, Carrara H, Patel M, Ruff P, Sur R, Jentsch U, Hale M, Rowji P, David S, Connor M, Bull D, Newton R, Valerie B: Epidemiology and Cancer Prevention. The spectrum of HIVI related cancers in South Africa. Int J Cancer 2000, 88:489-492.

6. Wright TCJ, Ellerbrock TV, Chiasson MA, Van Devanter N, Sun XW: Cervical intraepithelial neoplasia in women infected with human immunodeficiency virus: prevalence, risk factors, and validity of Papanicolaou smears. New York Cervical Disease Study. Obstet Gynecol 1994, 84(4):591-597.

7. Moodley J, Hoffman M, Carrara H, Allan B, Cooper D, Rosenberg L, Denny LE, Shapiro S, Williamson A: HIV and pre-neoplastic lesions and neoplastic lesions of the cervix in South Africa: a case control study. BMC Cancer 2006.

8. Parham G, Sahasrabuddhe V, Mwanahamuntu M, Shepherd B, Hicks $M$, Stringer E: Prevalence and predictors of squamous intraepithelial lesions of the cervix in HIV-infected women in Lusaka, Zambia. Gynecol Oncol 2006, I 03:1017-1022.

9. National HIV and syphilis antenatal sero-prevalence survey in South Africa, 2006 [http://www.doh.gov.za/docs/hiv-f.html].

10. National guidelines for cervical cancer screening in South Africa,2000 [http://www.doh.gov.za/docs/facts-f.html]

II. Cervical Cancer Screening: PHC Facilities. Precancerous and Cancerous Cervical smears, July-October 2006. Edited by: DoH . City of Johannesburg; 2006.

12. Cervical Screening Programme England: 2005-2006. NHS Health and Social care information centre, Statistical Bulletin 2006/24/ HSCIC, ISBN: I-84636-095-I.

13. Laara A, Day NE, Hakama M: Trends in mortality from cervical cancer in the Nordic countries: association with organized screening programs. Lancet 1987, 8544: I 247-I 249.

14. Boyes DA, Worth AJ, Anderson GH: Experience with cervical screening in British Columbia. Gynecol Oncol 198I, I 2( I 43): | 43-I55.

15. Soutter WP, Sasieni P, Panoskaltsis T: Long-term risk of invasive cervical cancer after treatment of squamous cervical intraepithelial neoplasia. Int J Cancer 2006, I I 8:2048-2055.

16. Solomon D, Davey D, Kurman R, Moriarty A, O'Connor D, Prey M, Raab S, Sherman M, Wilbur D, Wright TJ, Young N: The 200I Bethesda System.Terminology for reporting results of cervical cytology. JAMA 2002, 287(16):2 I I4-2II 9.

17. Cárdenas-Turanzas M, Follen M, Benedet JL, Cantor SB: See-andtreat strategy for diagnosis and management of cervical squamous intraepithelial lesions. Lancet Oncol 2005, 6:43-50.

18. Bosch FX, Lorincz A, Munoz N, Meijer CJ, Shah KV: The causal relation between human papillomavirus and cervical cancer. J Clin Pathol 2002, 55(4):244-265.

19. Sun XW, Kuhn L, Ellerbrock TV, Chiasson MA, Bush TJ, Wright TCJ: Human papillomavirus infection in women infected with the human immunodeficiency virus . N Engl J Med 1997, 337:1343-1349.

20. Conley LJ, Ellerbrock TV, Bush TJ, Chiasson MA, Sawo D, Wright TC: HIV-I infection and of risk of vulvovaginal and perianal condylomata accuminata and intraepithelial neoplasia: a prospective cohort study . Lancet 2002, 359:108-II3.

21. Lillo FB, Ferrari D, Veglia F, Origoni M, Grasso MA, Lodini S, Mastrorilli E, Taccagni G, Lazzarin A, Uberti-Foppa C: Human papillomavirus infection and associated cervical disease in human immunodeficiency virus-infected women: effect of highly active antiretroviral therapy. J Infect Dis 200I, I 84:547-55I.

22. Heard I, Schmitz V, Costagliola D, Orth G, Kazatchkine MD: Early regression of cervical lesions in HIV-seropositive women receiving highly active antiretroviral therapy. AIDS 1998, I 2(I 2): | 459-| 464.

23. Minkoff H, Ahdieh L, Massad LS, Anastos K, Watts DH, Melnick S, Muderspach L, Burk R, Palefsky J: The effect of highly active antiretroviral therapy on cervical changes associated with oncogenic HPV among HIV-infected women. AIDS 200I, I 5:2157-2 I64.

24. Richardson AT, Lyong JB: The effect of condom use on squamous cell cervical intraepithelial neoplasia. Am J Obstet Gynecol 1981, 140:909-9|3.

25. Hogewoning CJ, Bleeker MC, van den Brule AJ, Voorhorst FJ, Snijders PJ, Berkhof J, Westenend PJ, Meijer CJ: Condom use promotes regression of cervical intraepithelial neoplasia and clearance of human papillomavirus: a randomized clinical trial. Int J Cancer 2003, I 07(5):8। I-816. 
26. Branca M, Garbuglia AR, Benedetto A, Cappiello T, Leoncini L, Migliore G, Agarossi A, Syrjaren K: Factors predicting the persistence of genital human papillomavirus infections and PAP smear abnormality in HIV-positive and HIV-negative women during prospective follow-up. Int J STD AIDS 2003, 14:417-425.

27. Santos C, Galdos R, Alverez M, Velarde C, Barriga O, Dyer R, Estrada $\mathrm{H}$, Almonte $\mathrm{M}$ : One session management of cervical intraepithelial neoplasia: a soloution for deveoping countries. A prospective, randomized trial of LEEP versus laser excisional conization. Gynecol Oncol 1996, 6I(I): II-15.

28. Spitzer M, Chernys A, Seltzer V: The use of large-loop excision of the transformation zone in an inner-city population. Obstet Gynecol 1993, 82:731-735.

29. Adam Y, Van Gelderen CJ, Newell K: 'Look and Lletz'--a Chris Hani Baragwanath Hospital experience. S Afr Med J 2008, 98(2): I19-122.

30. Xi LF, Kiviat NB, Wheeler CM, Kreimer A, Ho J, Koutsky LA: Risk of cervical intraepithelial neoplasia grade 2 or 3 after loop electrosurgical excision procedure associated with human papillomavirus type 16 variants. J Infect Dis 2007, 195(9): I340-I 344.

31. Hernadi Z, Szoke K, Sapy T, Krasznai ZT, Soos G, Veress G, Gergely $\mathrm{L}$, Konya J: Role of human papillomavirus (HPV) testing in the follow-up of patients after treatment for cervical precancerous lesions. Eur J Obstet Gynecol Reprod Biol 2005, I I 8(2):229-234.

32. Costa S, de Simone P, Venturolli S, Cricca M, Zerbini ML, Musiani M, Terzano P, Santini D, Cristiani P, Syrjänen S, Syrjänen K: Factors predicting human Papillomavirus clearance in cervical intraepithelial neoplasia lesions treated by conization. Gynecol Oncol 2003, 90:358-365.

33. IARC: Monographs on the evaluation of carcinogenic risks to humans: Human Papillomaviruses. 1995, 64:I-409.

34. Reich O, Lahousen M, Pickel H, Tamussino K, Winter R: Cervical intraepithelial neoplasia III: long-term follow-up after coldknife conization with involved margins. Obstet Gynecol 2002 85:193-196.

35. Costa S, De Nuzzo M, Infante FE, Bonavita B, Marinelli M, Rubino A, Rambelli $V$, Santini $D$, Cristiani P, Bucchi L: Disease persistence in patients with cervical intraepithelial neoplasia undergoing electrosurgical conization. Gynecol Oncol 2002, 85(I): I I9-I 24.

36. Paraskevaidis E, Koliopoulos G, Malamou-Mitsi V, Zikopoulos K, Paschopoulos M, Pappa L, Agnantis NJ, Loli DE: Large loop excision of the transformation zone for treating cervical intraepithelial neoplasia: a I2-year experience. Anticancer Res 200I, 2I(4B):3097-3099.

37. Nappi L, Carriero C, Bettocchi S, Herrero J, Vimercati A, Putignano G: Cervical squamous intraepithelial lesions of low-grade in HIV-infected women: recurrence, persistence, and progression, in treated and untreated women. Eur J Obstet Gynecol Reprod Biol 2005, I 21:226-232.

38. Maiman M, Fruchter RG, Serur E, Levine V, Arrastia CD, Sedlis A: Recurrent cervical intraepithelial neoplasia in immunodeficiency virus-seropositive women. Obstet Gynecol 1993, 82(2): $170-174$.

39. Tate DR, Anderson RJ: Recrudescence of cervical dysplasia among women who are infected with human immunodeficiency virus: a case-control analysis . Am J Obstet Gynecol 2002, 186:880-882.

\section{Pre-publication history}

The pre-publication history for this paper can be accessed here:

\section{http://www.biomedcentral.com/1471-2407/8/211/pre} pub
Publish with Biomed Central and every scientist can read your work free of charge

"BioMed Central will be the most significant development for disseminating the results of biomedical research in our lifetime. "

Sir Paul Nurse, Cancer Research UK

Your research papers will be:

- available free of charge to the entire biomedical community

- peer reviewed and published immediately upon acceptance

- cited in PubMed and archived on PubMed Central

- yours - you keep the copyright
BioMedcentral 